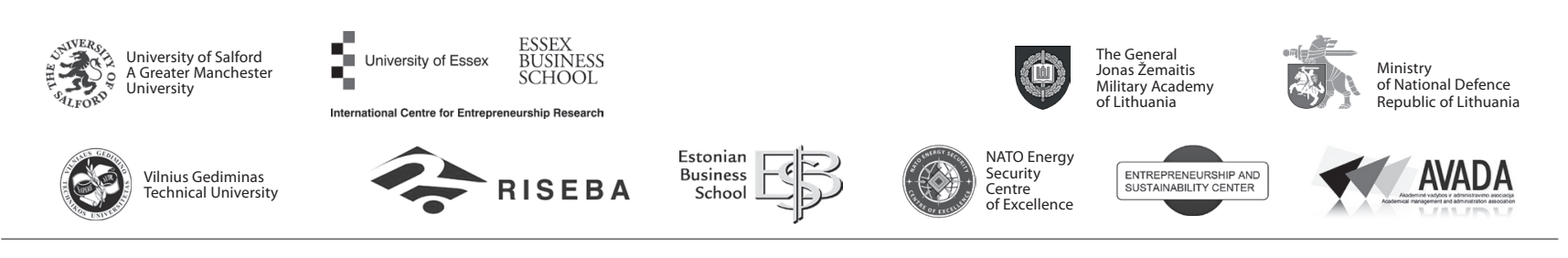

\author{
JOURNAL OF SECURITY AND SUSTAINABILITY ISSUES \\ ISSN 2029-7017 print/ISSN 2029-7025 online \\ 2017 December Volume 7 Number 2 \\ http://dx.doi.org/10.9770/jssi.2017.7.2(15)
}

\title{
CRIME OF THE TERRORIST CHARACTER AND EXTREMIST ORIENTATION IN THE RUSSIAN FEDERATION: STATE AND MEASURES OF COUNTERACTION
}

\author{
Vadim Avdeev$^{1}$, Olga Avdeeva ${ }^{2}$, Stanislav Rozenko3, Evgeniy Znamerovskiy ${ }^{4}$ Evgeniy Kiselyov $^{5}$ \\ ${ }^{1,3}$ Yugra State University, Chehov Str. 16, 628011, Hanty-Mansiysk, Russia \\ ${ }^{2}$ Baikal Gumanitary Institute, Marks Str. 35, 664000, Irkutsk, Russia \\ ${ }^{4}$ Pacific National University, Tikhookeanskaya Str. 136, 680035, Khabarovsk, Russia \\ ${ }^{5}$ Moscow Academy of the Investigative Committee of the Russian Federation, \\ Vrubel Str. 12, 125080, Moscow, Russia

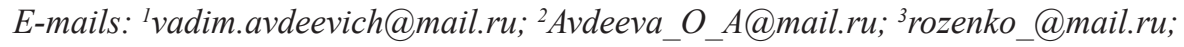

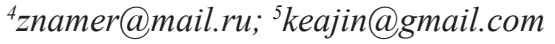

Received 12 February 2017; accepted 27 September 2017

\begin{abstract}
In this article the current trends of development of crime of the terrorist character and extremist orientation are investigated. On the basis of data of official statistics the state and structure of crime of terrorist character and extremist orientation are reflected. The tendency of steady growth of relative indicators of crimes of the terrorist character and extremist orientation is noted. Stimulation of activity of the terrorist and extremist organizations in the Russian Federation naturally inspired the further development of criminal and legal measures of counteraction of crime. Novelization of the criminal law has caused extension of the list of crimes of the terrorist character and extremist orientation. The restructuring of standards of the criminal law directed to the strengthening of measures of counteraction to encroachments of the terrorist character and extremist orientation is followed during the modern period mainly by criminalization and penalization of acts. The outlined tendency of growth of the criminal tension interfaced to development of the terrorist and extremist activity is reflected on the types and amount of the sentences imposed by the courts for the specified crimes. Special attention is paid to the measures of counteraction to the crimes of terrorist character and extremist orientation interfaced to an improvement of legal regulation of their prevention, stimulation of the state mechanism of counteraction of activity of the terrorist and extremist organizations, expansion of the international cooperation in the fight against terrorism and extremism.
\end{abstract}

In this regard the structure and activity of federal executive authorities, the system of identification, prevention and suppression of the acts of terrorism and extremism, mechanisms of prevention and counteraction to participation of the Russian citizens in the activity of criminal and terrorist groups abroad are a subject to improvement. Significant measures of security of the citizens and society from destructive information influence from the extremist and terrorist organizations are represented, scientific and technical support of the law-enforcement activity, perspective special means and equipment, the system of vocational training of specialists in the field of ensuring the state and public security.

Keywords: criminal and legal policy, terrorism, extremism, measures of counteraction to crimes of the terrorist character, extremist orientation

Reference to this paper should be made as follows: Avdeev, V.; Avdeeva, O.; Rozenko, S.; Znamerovskiy, S.; Kiselyov, E. 2017. Crime of the Terrorist Character and Extremist Orientation in the Russian Federation: State and Measures of Counteraction, Journal of Security and Sustainability Issues, 7(2): 359-367. DOI: http://dx.doi.org/10.9770/jssi.2017.7.2(15)

JEL Classifications: K42, O10, P00 


\section{Introduction}

In the conditions of modern globalization of international life and the growing opposition in the conditions of variety of legal and confessional systems of political and legal and social and economic interests of the states a threat to the world community is posed by building of the tendencies connected with a rise in crime of the terrorist character and extremist orientation.

The Declaration on measures for elimination of international terrorism approved by the Resolution of the United Nations General Assembly 46/90 of December 9, 1994 forms a legal basis for the interstate cooperation. International cooperation in counteraction to terrorism and extremism is provided with ratification by the national legislation of the norms of conventional international law. It is worth paying attention to the International convention on fight against bombing terrorism and the International convention on fight against the terrorism financing adopted by the Resolution of the United Nations General Assembly according to December 5, 1997 and December 9, 1999.

The international convention on suppression of the acts of nuclear terrorism from 9/14/2005 (New York) notes an expediency of cooperation of the states in the way: 1) conducting of different measures, including adaptation of the national legislation; 2) exchange of the exact and checked information. Efforts of the states are directed on ensuring protection of radioactive material, excepting the probability of nuclear terrorism.

Resolutions of the UN Security Council of 1999-2005 underline activization of the activities of international community for counteraction to the terrorism. The attention is deserved by the Resolution 1373 (2001) of September 28, 2001 on inadmissibility of financing of the terrorist activity and creation of the Counterterrorism committee. The Resolution 1540 (2004) of April 28, 2004 on the measures for counteraction of access for terrorists to the weapons of mass destruction is submitted timely. It is necessary to recognize relevant the Resolution 1624 (2005) of September 14, 2005 on inadmissibility of instigation to the acts of terrorism, counteraction to the ideology of terrorism and promotion of its ideas.

Among the regional normative legal acts the European convention on suppression of terrorism of January 27, 1977, the Convention of the Council of Europe on prevention of terrorism of May 16, 2005, the Shanghai convention on fight against the terrorism, separatism and extremism of June 15, 2001 deserve attention.

The contract of the State Parties of the Commonwealth of Independent States of October 5, 2007 on counteraction of legalization (washing) of criminal income and financing of terrorism provides the need of use of modern and effective remedies of fight against the terrorism. Special attention in this regard is paid to harmonization of the national legislation taking into account the international law in the sphere of counteraction of legalization (washing) of criminal income and the terrorism financing.

The convention of the Shanghai Cooperation Organization against the terrorism of June 16, 2009, considering the happened changes of scales and the nature of acts of the terrorism, provides strengthening the efforts in the fight against terrorism on condition of respect for the rule of law and democratic values, basic rights and freedoms of the person and the rules of international law.

The outlined negative tendencies of a condition of terrorism and extremism stimulated the need of improvement of the interstate system on ensuring the state and public security and further development of the international cooperation promoting the legal protection of inalienable rights and freedoms of each person. In this regard close attention has to be concentrated on an increase in the efficiency of measures directed to counteraction of crime of the terrorist character and extremist orientation.

Proceeding from the increased relevance, this problem has received lighting in the works of foreign and Russian scientists. Questions of expediency of unification of the measures of counteraction of crime of the terrorist character and extremist orientation have received lighting in the works of such jurists as P.V. Agapov, V. A. Avdeev, 
O. A. Avdeeva, V. V. Merkuryev, V. S. Komissarov, J. Teivāns-Treinovskis, N. Jefimovs, Я. C. ТейванТрейновский (Avdeev, Avdeeva 2013-2014, Agapov 2007, Merkuryev 2013, Teivāns-Treinovskis, Jefimovs 2012, Тейван-Трейновский 2016). Development of criminal and legal and criminological science is aimed at finding the most optimum measures providing to the combination of efforts of the states on counteraction of crime of the terrorist character and extremist orientation. Development of the crime of terrorist character and extremist orientation at the transnational level naturally demands harmonization of the criminal legislation of the foreign states.

\section{Condition of crime of the terrorist character and extremist orientation in the Russian Federation}

Steady growth in the crime of terrorist character and extremist orientation was outlined in the Russian Federation in 2010-2017. Dynamics of growth of the absolute and relative measures of crimes of the terrorist character is confirmed by the indicators which have reached in: $2010-581(0,022 \%) ; 2011-622(0,025 \%)$; 2012 - 637 (0,027\%); 2013 - 661 (0,029\%); 2014 - 1128 (0,051\%); 2015 - 1538 (0,064\%); 2016 - 2227 $(0,103 \%)$; January-July, $2017-1265(0,105 \%)$. Not less indicative is the dynamics of crimes of extremist orientation which is characterized by the following absolute and relative measures: $2010-656(0,024 \%)$; 2011 - 622 (0,025\%); 2012 - 696 (0,03\%); 2013 - 896 (0,04\%); $2014-1034$ (0,047\%); 2015 - $1329(0,055 \%)$; 2016 - 1450 (0,067\%); January-July, 2017 - 958 (0,079\%) (See Tab.1):

Table 1. Dynamics of crimes of the terrorist character

\begin{tabular}{|c|c|c|c|c|}
\hline Years & $\begin{array}{c}\text { Absolute measures } \\
\text { of crimes of the } \\
\text { terrorist character }\end{array}$ & $\begin{array}{c}\text { Relative measures } \\
\text { of crimes of the } \\
\text { terrorist character }\end{array}$ & $\begin{array}{c}\text { Absolute measures } \\
\text { of crimes of the } \\
\text { extremist orientation }\end{array}$ & $\begin{array}{c}\text { Relative measures } \\
\text { of crimes of the } \\
\text { extremist orientation }\end{array}$ \\
\hline 2003 & 8664 & $0,314 \%$ & 157 & $0,005 \%$ \\
\hline 2004 & 9523 & $0,329 \%$ & 130 & $0,004 \%$ \\
\hline 2005 & 5438 & $0,152 \%$ & 152 & $0,004 \%$ \\
\hline 2006 & 1781 & $0,046 \%$ & 263 & $0,006 \%$ \\
\hline 2007 & 759 & $0,021 \%$ & 356 & $0,009 \%$ \\
\hline 2008 & 642 & $0,02 \%$ & 460 & $0,014 \%$ \\
\hline 2009 & 654 & $0,021 \%$ & 548 & $0,018 \%$ \\
\hline 2010 & 581 & $0,022 \%$ & 656 & $0,024 \%$ \\
\hline 2011 & 622 & $0,025 \%$ & 622 & $0,025 \%$ \\
\hline 2012 & 637 & $0,027 \%$ & 696 & $0,03 \%$ \\
\hline 2013 & 661 & $0,029 \%$ & 896 & $0,04 \%$ \\
\hline 2014 & 1128 & $0,051 \%$ & 1034 & $0,047 \%$ \\
\hline 2015 & 1538 & $0,064 \%$ & 1329 & $0,055 \%$ \\
\hline 2016 & 2227 & $0,103 \%$ & 1450 & $0,067 \%$ \\
\hline January-July, 2017 & 1265 & $0,105 \%$ & 958 & $0,079 \%$ \\
\hline
\end{tabular}

Source: created by authors

The comparative analysis of these indicators shows that in January-July, 2017 absolute measures of crimes of the terrorist character in comparison with the identical period of the last year were the subject to decrease by $13,7 \%$. At the same time the tendency of growth by $5,5 \%$ of crimes of extremist orientation is noted. Thus, the relative indicators of the specified crimes, despite fluctuations of the absolute measures, keep a tendency of further growth. Thereof the specific weight of crimes of the terrorist character was $0,105 \%$, extremist orientation $-0,079 \%$.

The restructuring of standards of the criminal law directed to strengthening of the measures of counteraction to the encroachments of terrorist character and extremist orientation is followed during the modern period mainly by the criminalization and penalization of the acts. The outlined tendency of growth of the criminal 
tension interfaced to the development of terrorist and extremist activity is reflected in the types and amount of the sentences imposed by the courts for the specified crimes. In 2016 the share of convicts for crimes of the terrorist character and extremist orientation has made $0,13 \%$ of a total number brought to trial. Specific weight of convicts for the acts of terrorism and extremism is estimated in the ratio $44,88 \%$ and $55,12 \%$ (See Tab.2):

Table 2. Dynamics of convicts of the terrorist character

\begin{tabular}{|c|c|c|c|c|}
\hline Years & $\begin{array}{c}\text { Absolute measures } \\
\text { of convicts of the } \\
\text { terrorist character }\end{array}$ & $\begin{array}{c}\text { Relative measures } \\
\text { of convicts of the } \\
\text { terrorist character }\end{array}$ & $\begin{array}{c}\text { Absolute measures } \\
\text { of convicts of the } \\
\text { extremist orientation }\end{array}$ & $\begin{array}{c}\text { Relative measures } \\
\text { of convicts of the } \\
\text { extremist orientation }\end{array}$ \\
\hline 2009 & 217 & $0,026 \%$ & 87 & $0,01 \%$ \\
\hline 2010 & 203 & $0,024 \%$ & 135 & $0,015 \%$ \\
\hline 2015 & 334 & $0,045 \%$ & 483 & $0,065 \%$ \\
\hline 2016 & 434 & $0,058 \%$ & 533 & $0,071 \%$ \\
\hline
\end{tabular}

Source: created by authors

The analysis of relative indicators of the convicts allows note a dominant position brought to the trial for arousing hatred or hostility, and humiliation of human dignity (The art. 282 of the Criminal Code of the Russian Federation) $-40,84 \%$ is equal. The second position in this list is taken by the indicators of convicts for the organization of illegal armed group or participation in it (The art. 208 of the Criminal Code of the Russian Federation) $-26,16 \%$. Deserve attention of a share condemned according to the art. 205-2055 of the Criminal Code of the Russian Federation - 17,26\% and the art. 280 of the Criminal Code of the Russian Federation - 11,68\%. Minimum indicators of convicts for the other crimes of terrorist character and extremist orientation which in total have made $(4,06 \%)$ are represented (See Tab.3):

Table 3. Dynamics of indicators of the convicts for arousing hatred or hostility, and humiliation of human dignity

\begin{tabular}{|l|c|c|c|c|}
\hline Years & $\begin{array}{c}\text { Relative indicators } \\
\text { of the convicts for } \\
\text { arousing hatred or } \\
\text { hostility, and humiliation } \\
\text { of human dignity }\end{array}$ & $\begin{array}{c}\text { Relative indicators } \\
\text { of the convicts for the } \\
\text { organization of illegal } \\
\text { armed group or } \\
\text { participation in it }\end{array}$ & $\begin{array}{c}\text { Relative indicators of the } \\
\text { convicts to the art. } \\
205-205.5 \text { of the Criminal } \\
\text { Code of the Russian } \\
\text { Federation }\end{array}$ & $\begin{array}{c}\text { Relative indicators } \\
\text { of the convicts } \\
\text { to the art. 280 } \\
\text { of the Criminal Code of } \\
\text { the Russian Federation }\end{array}$ \\
\hline 2009 & $21,38 \%$ & $50,98 \%$ & $7,23 \%$ & $5,59 \%$ \\
\hline 2010 & $31,06 \%$ & $43,78 \%$ & $2,95 \%$ & $5,62 \%$ \\
\hline 2015 & $46,26 \%$ & $29,49 \%$ & $8,44 \%$ & $7,83 \%$ \\
\hline 2016 & $40,84 \%$ & $26,16 \%$ & $17,26 \%$ & $11,68 \%$ \\
\hline
\end{tabular}

Source: created by authors

The priority place in the system of punishments for the crimes of terrorist character is allocated to imprisonment for a certain term $-87,78 \%$. The remained types of punishments were distributed as follows: conditional condemnation to imprisonment $-6,91 \%$; a penalty $-3,45 \%$; restriction of freedom $-0,92 \%$; lifelong imprisonment $-0,46 \%$ (See Tab.4): 
Table 4. Dynamics of indicators of crimes and convicts

\begin{tabular}{|l|c|c|c|c|}
\hline \multicolumn{1}{|c|}{$\begin{array}{c}\text { System of } \\
\text { punishments }\end{array}$} & $\begin{array}{c}\text { Convicts for } \\
\text { crimes of the } \\
\text { terrorist character }\end{array}$ & $\begin{array}{c}\text { Relative } \\
\text { indicators } \\
\text { of the convicts }\end{array}$ & $\begin{array}{c}\text { Convicts for } \\
\text { crimes of the } \\
\text { extremist orientation }\end{array}$ & $\begin{array}{c}\text { Relative } \\
\text { indicators } \\
\text { of the convicts }\end{array}$ \\
\hline Allocated to imprisonment for a certain term & 381 & $87,78 \%$ & 57 & $10,69 \%$ \\
\hline Conditional condemnation to imprisonment & 30 & $6,91 \%$ & $37,96 \%$ \\
\hline A penalty & 15 & $3,45 \%$ & 75 & $14,07 \%$ \\
\hline Restriction of freedom & 4 & $0,92 \%$ & 0 & $0,0 \%$ \\
\hline Life long imprisonment & 2 & $0,46 \%$ & 0 & $0,0 \%$ \\
\hline Obligatory works & 0 & $0,0 \%$ & 37 & $20,07 \%$ \\
\hline Corrective works & 0 & $0,0 \%$ & 18 & $6,94 \%$ \\
\hline Conditional condemnation to the other measures & 0 & $0,0 \%$ & 1 & $3,37 \%$ \\
\hline Keeping in a disciplinary military unit & 0 & $0,0 \%$ & $0,18 \%$ \\
\hline
\end{tabular}

Source: created by authors

The research of indicators of the convicts for crimes of extremist orientation has allowed reveal the following regularities. Dominatingin the judicial activityare recognized conditional condemnation to imprisonment$36,96 \%$, obligatory works $-20,07 \%$ and a penalty $-14,07 \%$. The following on a degree of prevalenceare: imprisonment for a certain term $-10,69 \%$; corrective works $-6,94 \%$; conditional condemnation to the other measures $-3,37 \%$; keeping in a disciplinary military unit $-0,18 \%$.

\section{Novelization of the criminal law on counteraction of the crime of terrorist character and extremist orientation in the Russian Federation}

Stimulation of activity of the terrorist and extremist organizations in the Russian Federation naturally inspired further development of the criminal and legal measures of counteraction of crime. As one of the directions of counteraction of crime of the terrorist character and extremist orientation criminalization and a penalization of acts are chosen. The undertaken novelization of the criminal law has caused extension of the list of crimes of terrorist character and extremist orientation. The acts regulated by the art. 205-2055, 206, 208, 211, 220, 221, 277-279, 360, 361 of the Criminal Code of the Russian Federation are recognized as the crimes of terrorist character. The extremist orientation characterizes the crimes provided by the art. 280, 2801, 282-2823 of the Criminal Code of the Russian Federation.

The restructuring of standards of the criminal law directed to strengthening of measures of counteraction to encroachments of the terrorist character and extremist orientation continues during the modern period. As confirmation serves the Federal law from 7/6/2016 of No. 375-FL which has increased the maximum limit of punishment in the first and second parts to the art. 205 of the Criminal Code of the Russian Federation for the act of terrorism without the aggravating circumstances and in the presence of those respectively up to ten and twelve years of imprisonment.

The analyzed federal law has changed representation concerning the list of crimes of the terrorist character. The possibility of qualification of the realized act according to the article 2051 of the Criminal Code of the Russian Federation on a condition of inducement, recruitment or other involvement of the person in commission of the crimes provided by the art. 2052-2054, 220, 221, 361 of the Criminal Code of the Russian Federation turns out to be consequence of it.

The set of crimes forming the objective side of assistance to the terrorist activity is a subject to expansion. The sphere of complicity allows qualify the act according to the p. 3 of the art. 2051 of the Criminal Code of the Russian Federation includes along with a commission of crimes provided by the art. 205 of the Criminal Code of the Russian Federation in addition also the p. 3 of the art. 206, p.1 of the art. 208 of the Criminal Code of the Russian Federation. 
Identical approach is used when determining a concept of financing of terrorism. The required concept means granting or fund raising or rendering financial services with awareness of their mission for financing of the organization, preparation or the commission of crime regulated by the art. 205, 206, 208, 211, 220, 221, 277-279, 360 of the Criminal Code of the Russian Federation.

It should be noted that the sanction p. 1 of the art. 205 of the Criminal Code of the Russian Federation which has kept only a penalty and imprisonment for a certain term as the main types of sentences imposed for public calls for implementation of terrorist activity or public justification of terrorism is a subject to change. Addition of a disposition of the norm provided by the part 2 of the article 205 of the Criminal Code of the Russian Federation indicates a possibility of commission of this crime not only with a use of mass media, but also electronic or information and telecommunication networks, including the Internet network.

High degree of public danger of the public calls for implementation of the terrorist activity or public justification of terrorism made by the use of mass media, electronic or information and telecommunication networks, including the Internet network, is reflected in the sanction of the norm regulated by the p. 2 of the art. 205 of the Criminal Code of the Russian Federation from the contents of which are excludedtheforced works. The lower limit of punishment in the form of imprisonment for five years - is at the same time designated. In this regard the imposed sentence taking into account the sanction of the considered criminal precept of law varies ranging from five up to seven years of imprisonment that significantly limits a judicial discretion at a removal of conviction.

The federal law from 7/6/2016 No. 375-FL regulated the legal execution of the note 2 to the art. 205 of the Criminal Code of the Russian Federation according to whichthe terrorist activity is formed as a result of commission at least of one of the crimes provided by the articles 205-206, 208, 211, 220, 221, 277-279, 360, 361 of the Criminal Code of the Russian Federation.

The feature of novelization of the Russian criminal legislation is connected with introduction by the Federal law of 06.07.2016 No. 375-FL of the article 361 of the Criminal Code of the Russian Federation regulating the act of the international terrorism allowed select within the crimes against the world and safety of mankind one more crime of the terrorist character. The specific of this crime consists in its objective side including: 1) making outside the Russian Federation of explosion, an arson or other actions endangering life, health, freedom or inviolability of the citizens of the Russian Federation; 2) threat of implementation of the specified actions. The pursued purposes have the qualifying value: a) connected to violation of peaceful co-existence of the states and the people; b) directed against the interests of the Russian Federation.

Accordingto the p. 1 of the article 361 of the Criminal Code of the Russian Federation commission outside the Russian Federation of explosion, arson or the other actions endangering life, health, freedom or inviolability of citizens of the Russian Federation or the threat of implementation of the specified actions for the purpose of violation of peaceful co-existence of the states and the people or directed against the interests of the Russian Federation, is recognized as especially serious crime. The act of international terrorism attracts on the part 1 punishment from ten to twenty years of imprisonment or the lifelong imprisonment.

Financing of the act of international terrorism or involvement in committing of the specified acts is qualified according to the p. 2 of article 361 of the Criminal Code of the Russian Federation. The sanction of this norm prescribes punishment from five to ten years of imprisonment or a penalty to five hundred thousand rubles.

The legal treatment of act is a subject to change on the p. 3 of the art. 361 of the Criminal Code of the Russian Federation if the death of the person becomes a result of commission of the crime provided by the part one of analyzable article. In this case the lower limit of punishment in the form of imprisonment is a subject to increase. In this regard in the third part the punishment from fifteen to twenty years of imprisonment is prescribed. Gain of a retaliatory entity of a main type of punishment is promoted by the restriction of freedom for a period of one year up to two years. As an alternative to imprisonment on a certain period in the sanction of criminal precept of law the lifelong imprisonment is regulated. 
It is remarkable that the act of international terrorism criminalized in the art. 361 of the Criminal Code of the Russian Federation includes in the content of dispositions of the norms regulating the crimes of terrorist character provided by the articles 205, 205 of the Criminal Code of the Russian Federation. Identical addition is used in case of legislative design of the note to the article 205 of the Criminal Code of the Russian Federation. The lower and upper amount of punishment respectively up to ten and twenty years of imprisonment is a subject to double increase in the sanction of norm of the articles 205, 205 of the Criminal Code of the Russian Federation.

In the course of increase in the efficiency of measures of counteraction to the terrorism the essential value is gained by the optimization of the law-enforcement activity interfaced to the correct qualification of crimes of the terrorist character. On the questions connected with the exact legal evaluation of the specified corpora delicti focuses the Resolution of the Plenum of the Supreme Court of the Russian Federation from 11/3/2016 of No. 41 "About introduction of amendments to the resolution of the Plenum of the Supreme Court of the Russian Federation of February 9, 2016 No. 1 "About some questions of jurisprudence on criminal cases about the crimes of terrorist orientation" and of June 28, 2011 No. 11 "About jurisprudence on criminal cases about the crimes of extremist orientation".

At the same time activization at the present stage of activity of the terrorist and extremist organizations in the Russian Federation inspires a search of new measures of counteraction to the terrorism and extremism in the context of transnational nature of crime complicating the interstate control and acceptance of advancing measures of counteraction of the activity of terrorist and extremist criminal formations.

At the choice of interstate measures of counteraction to this type of crime the broad orientation of activity of the terrorist and extremist criminal formations connected with the violent change of constitutional system has special value; destabilization of work of the public authorities; destruction or violation of functioning of the military, industrial facilities; elimination of critical public infrastructure, transport infrastructure; intimidation of the population. Realization of terrorist and extremist activity assumes taking by the weapons of mass destruction, radioactive, poisoning, toxic, chemically and biologically dangerous substances, generates a threat of implementation of the acts of nuclear terrorism and also the safety and stability of functioning of critical information infrastructure of the state. Implementation of the terrorist and extremist activity, interfaced to the use of information and communication technologies, attracts distribution and promotion of the ideology of fascism, extremism, terrorism and separatism. As a result of activity of the terrorist and extremist criminal formations damage is caused to the civil world, consent, political and social stability in the society. Along with the state and public security also the other objects of criminal legal protection are exposed to encroachments. The outlined tendencies of growth of terrorism and extremism also actualized a problem of ensuring the state and public security, criminal legal protection of the inalienable rights and freedoms of the person.

It should be noted that development of the new directions of criminal and legal policy of the Russian Federation on counteraction to the terrorism and extremism, combination of the law-making, administrative, organizational and practical, control and supervising means which are based on the standards of international and domestic constitutional legislation have predetermined an increase in the efficiency of national mechanism of criminal legal protection of the human right on life.

\section{Conclusions}

Relevant directions of counteraction of crime of the terrorist character and extremist orientation. The key directions of ensuring the state and public security at the present stage are: 1) strengthening of a role of the state as the guarantor of safety of the specified interests; 2) improvement of legal regulation of prevention of crime of the terrorist character and extremist orientation; 3) stimulation of the state mechanism of counteraction of activity of the terrorist and extremist organizations; 4) improvement of interaction of the bodies of ensuring the state security and law and order with the civil society; 5) increase in the trust of citizens to the law-enforcement and judicial systems; 6) optimization of the efficiency of protection of the rights and legitimate interests of the Rus- 
sian citizens abroad; 7) expansion of the international cooperation in the fight against terrorism and extremism. For ensuring the state and public security further improvement is demanded: a) the structure and activity of the federal executive authorities; b) the system of identification, prevention and suppression of the acts of terrorism, manifestations of religious radicalism, nationalism, separatism and the other forms of extremism; c) the mechanisms of prevention and neutralization of the social and international conflicts and also counteractions to participation of the Russian citizens in activity of the criminal and terrorist groups abroad; d) the regime of safe functioning, the level of anti-terrorist security of the organizations of defensive and industrial, nuclear, chemical, fuel and energy complexes of the country, critical public infrastructure, transport infrastructure, other crucial and potentially dangerous objects raise; e) the measures of security of the citizens and society from the destructive information influence from the extremist and terrorist organizations; e) the scientific and technical support of the law-enforcement activity, perspective special means and equipment, the system of vocational training of specialists in the field of ensuring the state and public security.

Oppression of the terrorist and extremist crime has to be promoted by an increase in social responsibility of the bodies of ensuring the state and public security. Such approach promotes oppression of corruption components and is followed by a development of the system of the scientific, design and scientific and technological organizations capable to ensure the state and public security. Criterion for evaluation of the efficiency of realized activity is satisfaction of the citizens with a degree of security of the constitutional rights and freedoms from the crimes of terrorist character and extremist orientation.

\section{References}

Agapov P.V., Mikhaylov K.V. 2007. Criminal liability for assistance of terrorist activity: tendencies of modern criminal policy. Saratov.

Aggarwal, Neil Krishan. 2016. The Taliban's Virtual Emirate: The Culture and Psychology of an Online Militant Community. New York: Columbia University Press.

Anaya, Kala Kristina Hartman. 2015, July. Persuasion Strategies in Terrorist Recruitment: The Case of ISIS.(Master's Thesis, Leiden University, Leiden, The Netherlands). URL: https://openaccess.leidenuniv.nl/handle/1887/35008

Avdeev V.A., Avdeeva O.A. 2014. Criminal legal concept of the Russian Federation: main directions of criminal law improvement and crime counteraction measures optimization. Criminology Journal of Baikal National University of Economics and Law. No. 1. Pages $12-24$.

Avdeev V. A., Avdeeva O.A. 2014. Main directions of national criminal and legal policy in the sphere of counteraction of crime realization: federal and regional principles comparative analysis. Criminology Journal of Baikal National University of Economics and Law No. 2. Pages 46-62.

Avdeev V. A. 2013. Purposes of punishment optimization in the context of crime prevention. Criminology Journal of Baikal National University of Economics and Law. No. 2. Pages 41-53.

Baal' N.B. 2012. Political extremism of the Russian youth and technology of its overcoming: abstract ofdiss. ofthe Doctor of political sciences. N. Novgorod.

Bodine-Baron, Elizabeth et al. 2016. Examining ISIS Support and Opposition Networks on Twitter. [e-Book]. (RAND Research Reports, RR-1328-RC). Santa Monica: RAND Corporation. https://doi.org/10.7249/ RR1328

Bouchard, Martin. 2015. Social Networks, Terrorism and Counter-Terrorism: Radical and Connected. (Contemporary Terrorism Studies). Abingdon: Routledge.

Briant, Emma Louise 2015. Propaganda and Counter-Terrorism: Strategies for Global Change. Manchester: Manchester University Press.

Carter Center, The (Ed.) 2016. Countering Daesh Propaganda: Action-Oriented Research for Practical Policy Outcomes. (Workshop Report). Atlanta: The Carter Center. URL: https://www.cartercenter. org/resources/pdfs/peace/conflict_resolution/countering-isis/ counteringdaeshpropaganda-feb2016.pdf

Grover, Sonja C. 2011. Schoolchildren as Propaganda Tools in the War on Terror: Violating the Rights of Afghani Children under International Law. Heidelberg: Springer. https://doi.org/10.1007/978-3-642-17900-6 
Merkuryev V.V., Agapov P.V. 2013. Criminological characteristic of the crime connected with the organization of extremist community. Criminology Journal of Baikal National University of Economics and Law. No.1. Pages 26-35.

Teivāns-Treinovskis, J.; Jefimovs, N. 2012. State national security: aspect of recorded crime, Journal of Security and Sustainability Issues 2(2): 41-48. https://doi.org/10.9770/jssi.2012.2.2(4).

Тейван-Трейновский Я.С. 2016. Оценка социальных факторов и условий девиантного поведения в современном обществе / Я. С. Тейван-Трейновский, О.Я. Лавриненко, Криминологический журнал Байкальского государственного университета экономики и права 10(1): 73-81. https://doi.org/10.17150/1996-7756.2016.10(1).73-81.

Vadim AVDEEV - Grand PhD in law science, Professor, Professor of the Law Institute of the Yugra State University. Research interests: criminal law, criminology.

Olga AVDEEVA - Grand PhD in law science, Professor, Professor of the law faculty of the Baikal Humanitarian Institute. Research interests: state law, rights of the human, criminology.

Stanislav ROZENKO - Candidate of Law, Associated Professor, Director of the Law Institute of the Yugra State University. Research interests: criminal law, criminology.

Evgeniy ZNAMEROVSKIY - Candidate of Law, Associate Professor of the chairof the state and the law andhistory of Russia of the Pacific State University. Research interests: state law, rights of the human, criminology.

Evgeniy KISELYOV - Candidate of Law, Head of the criminalistics laboratory of the fifth training faculty Moscow Academy of the Investigative Committee of the Russian Federation. Research interests: state law, rights of the human, criminology. 